\title{
Rethinking Brand Identity to Become an Iconic Brand - A Study on Pepsi
}

\author{
Reaz Hafiz* \\ Lecturer, School of Business Studies, Southeast University, Dhaka, BANGLADESH \\ *E-mail for correspondence: rocking reaz@yahoo.com \\ Cell Phone: +8801614336620
}

\begin{abstract}
One of the leading brands, Pepsi has battled time to time for getting success in the Cola industry by developing different slogans, ideas, celebrity endorsement, campaigns and other marketing efforts. These never ending quests for growth and market share are not always ended with positive notes because of miss fire of strategies. The focus of the paper is to identify current position and rebranding issues regarding Pepsi along with the ways to make it an iconic brand. In the first part of this paper, Holt's concept has been used to analyze Pepsi Cola's history and current position to establish whether and if yes to which extent this brand has managed to become iconic. The second part is dedicated towards developing and suggesting a future course of action for the company that would enable it once again becoming an iconic brand.
\end{abstract}

Keywords: Pepsi, Brand Identity, Rebranding, Myth

JEL Classification Code: M31

\section{INTRODUCTION}

In order to stay relevant, and connect with (post)modern consumers and other stakeholders, brands must be engaged in the negotiations of cultural identity in society (Csaba and Bengtsson, 2006). Since its introduction in 1898, Pepsi has battled for success, both on its own and in comparison to its main competitor Coca-Cola. Throughout the years, the company has used number of slogans, ideas, celebrities, campaigns and ways of market itself to the public in a never-ending quest for growth and market share. Sometimes, the campaigns worked, sometimes they failed, the underlying causes of success or failure mostly remaining a mystery to executives, marketers and consumers.

New insights have been gained now a day, one of the approaches is being the concept of brands as cultural icons by Holt (2004). Using this approach, positive or negative brand achievements can be explained based to the extent to which a company or brand manages to address and resolve relevant cultural contradictions in society. In connection with concepts such as authenticity, relational branding, identity; this approach has been proven to be a useful tool in both explaining and forecasting (un) successful branding strategies.

\section{OBJECTIVE}

The major idea of this paper is to address Pepsi's brand position in the mind of US target market under the concept of brands as cultural icons by Holt where it covers three brand building blocks of national ideology, populist worlds and cultural contradictions. Another objective is to find out a new populist world for Pepsi to embody a new brand myth to become an iconic brand.

\section{Methodology}

The paper tries to highlight the problems of image positioning of a world famous brand "Pepsi" and ways to come out from the crisis to become an iconic brand. So the total work is exploratory in nature. The research method is adopted to find out the relevant articles to address the problems and possibilities in the cola market. The study is compiled by secondary sources of data such as books, online journals publications and internet sources. The study is concentrated towards the field of brand management. The references are given in the end section of the paper.

\section{SIGNIFICANCE OF THE STUDY}

This paper can be ideally significant to address the possibilities of positive image positioning of a brand that is popular but confusing to its customers. According to Holt concept, the author tried to focus Pepsi's past, current position and future possibilities in US market. To become an iconic brand, Pepsi's struggle is clearly depicted in the study. The paper significantly addressed the problem of losing position of Pepsi Cola by overusing celebrity instead of addressing relevant contradictions in society and helping citizens to build their identity. Beside this, the author also tried to find out the possible ways to rebuild the brand 
identity of Pepsi to become an iconic brand. It may provide a platform for empirical evidence to address the ways for positive influence in the firm's constructive image in today's competitive market.

\section{PART I - THE PAST}

\section{Pepsi's Brandscape}

The definition of a brandscape can be expressed as "the competitive and consumer environment in which your brand must perform and compete" (Kilmer \& Kilmer, 2001). It is clear that the geographic and product field of research has to be defined. This paper focuses on the US market. Furthermore, this paper centres on the "black" caffeinated drinks and does not consider other soft drinks such as Sprite, Fanta or Mountain Dew.

Using the classical product perspective, Coca-Cola is the main competitor for Pepsi on the US market. In other countries, local brands may have an important role, as for instance Mojo in Bangladesh in hot summer or Julmust in Sweden in the winter season or Afri Cola in Germany. However, there are no relevant local brands on the US market. Rather, substitutes such as tea, sports beverages and juices have lately started to play an increasing role and have to be taken into account (Elliott, 2008).

As Holt emphasizes, identity brands compete with cultural products as films, sports and books to perform myths that fill the gap between the national ideology and the personal standpoint (Holt, 2004: 39). That means, it is not enough for Pepsi to consider Coca-Cola as their competitor on the US market. Based on Holt's idea, it has to be considered that the company is participating and competing in myth markets. Coca-Cola would therefore only be a competitor if they were competing for the same myth.

\section{The Myth Market}

The structure of the myth market as Holt argues is built on three blocks; national ideology, populist worlds and cultural contradictions (Holt, 2004: 56). Holt described national ideology as a system of ideas that forges links between everyday life and those of the nation. The identity myth is based on populist world - often marginalized worlds characterized by their inhabitants sharing a special way of life (ethos) which creates the foundation for all their actions. The cultural contradictions increase, because citizens often do not inhabit the nation's ideology. It is stressed that "many people aspire to the nation's ideals, but have trouble seeing how their live matches up" (Holt, 2004: 57). It explains why these cultural contradictions create a demand for myths. So Pepsi has to find myths to bridge the gap, allowing people to work successfully on their identity projects.

It is thus of utmost importance for Pepsi to consider the present national ideology. Due to the long history of Pepsi, the brand has experienced changing national ideologies of the USA over time. In the upcoming part of the paper, different myths used by Pepsi over time to address the predominant contradictions in society will be described.

\section{The Cultural Brief}

The cultural brief can be stated as creative brief of a brandscape of a brand (Holt, 2004: 63). There are three elements that have to be considered; myth treatment, populist authenticity and the charismatic aesthetic. More in detail, it can be said that the brand's proposed role in the culture has to be figured out. Also, authenticity has to be demonstrated. According to Holt a company should use a distinctive and charismatic style to be successful in delivering the message (Holt, 2004: 64).

\section{THREE MYTH MARKETS}

\section{1st: "The American Dream" (1950-1960)}

The first analyzed myth used by Pepsi started around the 50 s until the 60s and is in this paper called the "American dream". The myth treatment or the story that embodies the brand's proposed role in culture is tied to the American Dream. The national ideology in US at that time was marked by national pride, freedom, power, and equality. It was emphasized that everyone, even the underdog, could make it. Pepsi took the role of helping the people to reach this ideology (Wikipedia, 2015). The company showed for instance through its advertisements what people have to do to 'make it', implicitly stating that by just following the ads command, people could be successful.

Iconic brands have to gain authenticity in the populist world via their actions. They have to deliver on 'literacy' and 'fidelity' to earn the respect of the populist world they are mining (Holt, 2004: 65). It demonstrates that Pepsi cannot just rely on populist worlds but also has to find a way to be authentic. In the case of the "American Dream" myth, Pepsi relied on strong patriotism, politicians and American icons, which helped them to achieve the desired American dream. The advertising was patriotic and uplifting too. The charismatic aesthetic of Pepsi during this time (and still today) was the use of the colours of the American flag for their brand. It focused and underlined that Pepsi is a real American drink. Also, this type of decor enabled people to show their national pride by using Pepsi.

\section{2nd: Youth Frontier / The Pepsi Generation (1961-1982)}

Next, Pepsi started to focus explicitly on building a myth connected to young generations who are heavily polarized choosing between Coca-Cola and Pepsi. The period 1960-1990 has been known as the period of the 'Cola wars'. In this period Coca-Cola was engaged excessively on building upon themes related to universality, traditional, conformity. Pepsi's formulation was built on concepts such as young, independent, adventurous, leading edge, future oriented \& entertaining - more explicitly 'the choice of a new generation' (Franzen and Moriarty, 2009).

As discussed before, the myth treatment is a proposed way which connects a brand to its culture and more explicitly the target audience. Therefore, it is important 
that the suggested approach of a myth from a sociocultural perspective cannot be misunderstood, particularly in this segment. Pepsi's formula of branding with breaking barriers between age groups happened to be quite a successful one. The myth established was not generally to patronize the young generations, but to enrich a value within the social system by introducing a distinguishing factor in the Cola industry - 'drinking Pepsi and feeling young' (Moraru, 2010). The author would like to explain a few of the marketing campaigns of that era, to explore the hidden underlying strategy within the myth, the national ideology, and the charismatic aesthetic part of the brand.

The myth started with a hard-hitting slogan back in 1961, "Now it is Pepsi for those who think young" (Wikipedia, 2015). The slogan manifested the idea of thinking young by utilizing the brand while promoting the formula of life which is always young. Followed by this, Pepsi's 1963 slogan - "Come alive, you are in Pepsi generation" (Wikipedia, 2015) is focused on similar characteristics introducing Pepsi generation to the US culture. This made history within the advertisement industry. Though commercially appealing, the product was not being identified by its attributes, but rather by its establishment of the theory of lifestyle attitudes. Later on, Pepsi employed several themes on the same formula to sustain the same myth, for instance- -“Taste that beats others cold-Pepsi pours it on" - (1967), "You've got a lot to live, and Pepsi got a lot to give" (1969); "Have a Pepsi day" (1975), "Join the Pepsi people"' (1977), (Wikipedia, 2015) (Moraru, 2010).

Pepsi's formulation of myth building within this period was commercially successful, followed up by many interesting examples of commercials. The main objective was to instigate on marketing towards teenagers and adults, known as the 'new generation of consumers'. As described by Holt (2004), US citizens' aspiration to reach national ideals and the often unsatisfying reality result in cultural contradictions as people find it difficult to attain the set goals. Therefore, Holt's (2004) cultural contradictions are important to discuss here within Pepsi's framework. According to Holt, "these tensions between ideology and individual experience produce intense desires and anxieties fuelling demand for symbolic resolutions that smooth over the tensions" (Holt, 2004: 58). Apparently, "national ideologies create models for living" (Holt, 2004: 59) and the differences between these models and everyday lives increase the pressure of creating myths to cover up the contradictions. Therefore, Pepsi got the formula right in this era by successfully crafting the model of lifestyle and attitudes which is being perceived as minimizing the gap between the national ideology and everyday life. It helped to cover up the cultural contradictions with the instalment of the feeling that 'those who drinks Pepsi belong to the same generation - the Pepsi generation where there is no age barrier, people can think, believe and react themselves as young as they want while drinking Pepsi'.

\section{3rd: Reinventing Pepsi, American Music and Celebrity Endorsement (1983-2008)}

It is an immensely difficult task to pull up a brand and revitalize its potential via new frameworks of branding, especially if the brand name is well known as 'Pepsi'. During the 80's, music happened to be an integral part of American culture with heavy names as Michael Jackson, emerging pop culture and a society which worshipped celebrity in the fields of entertainment (Wikipedia, 2015). The creative notion of Pepsi was to abandon the concept of youthfulness and to instead introduce a new myth market - the one of celebrities and American music. It seems a good idea to discuss the failure of Pepsi in the establishment of a myth market through analyzing several Pepsi commercials from that time before discussing possible courses of action for the future.

The concepts of national ideologies have already discussed, also the addressing of cultural contradictions within the myth establishment, the essence of a populist world and the need for authenticity. Therefore, the story telling around the myth whether it focuses on celebrity endorsement or American music needs to tell a central story which the audience or the subjected populist world could easily connect or understand. On the other hand, if the advertising campaigns are followed up by different themes for the same brand within the same periods, the perceptions get misunderstood. It can receive mixed reactions, and often leave the brand a prime example of failure to become iconic. The first commercial of Pepsi within that period was with Michael Jackson, where several kids from the street with different ethnic orientations were shown sharing moves with the pop-star, which became an enormous commercial success (Wikipedia, 2015). However, from the audiences' point of view, the concept of the commercial was often misleading since it was quite difficult to understand whether Pepsi was trying to work on the theme of racial equality of American culture or bridging the gap between the celebrity and regular people or a childhood fantasy coming true for a kid by dancing with Michael Jackson while drinking Pepsi. Several commercials followed the first one. In one advertisement Pepsi used Michael Jackson's famous song 'BAD' as a Pepsi theme, which received mixed responses since many followers did not like the association of the word 'BAD' with Pepsi (Bachmeier, 2008). A 1994 commercial with Van Halen's composition of 'right now' was a massive commercial success due to the immense popularity of rock band ' Van Halen' (Wikipedia, 2015). Later on, Pepsi was endorsed by several celebrities such as Britney Spears' (1999) solo commercial, Ricky Martin's Pepsi generation next (2000), Pepsi Gladiator theme Britney Spears, Pink, and Beyonce -we will rock you (2004), Jennifer Lopez \& Beyonce (2003), Mariah Carey (2006), Shakira (2006), Christina Aguiera, Justin Timberlake, Rihanna, Akon and so on (Wikipedia, 2015). The similarities among the celebrities starring in all these commercials had a huge fan following based on their style of music. However, from a critical point of view, these commercials were failing 
to instigate a singularity within the myth market; rather introducing a lot of different perceptions and phenomena, often even within the same commercial. It was even believed to be a fact that Pepsi was trying to explore the coolness of American music with their branding. But then again Pepsi employed Justin Timberlake in a Super Bowl commercial without the music - which created confusion concerning the target segments of Pepsi. The major catastrophic failure was 'Gladiator' advertisement in 2004, where several Pop stars dressed as gladiators were singing one of the most popular rock songs ever 'We will rock you' from Queen. It received negative reactions since the audience could not connect to the theme of dressing Pop stars as gladiators and making them sing a legendary rock song (Bachmeier, 2008). Some of the Pepsi commercials from that period were exaggerated and failed in conveying a single theme that could connect the populist world to with the audiences even though they were commercially successful (Bachmeier, 2008).

From a theoretical perspective, the viability of these later pop commercials can be questioned because of the failure to concentrate on a single theme. One could argue that Pepsi had emphasized the usage of celebrities and American music too much, without concurring on a single myth market. It left the audiences in a dilemma to decide upon a single entity which they could follow or adopt from the commercials. Therefore, the usage of celebrities and American Music could have been a very charismatic aesthetic from Holt's principles if these were beautifully portrayed within the national ideology (Holt, 2004).

\section{Interplay - The Present Situation}

As has been shown in above, Pepsi has managed to address and resolve US-American cultural contradictions in a way that enabled the brand to rise above others, to become an iconic brand. However, the situation nowadays is somewhat problematic. Pepsi has during the last 20 years not at all managed to use the correct identity myths and to develop a charismatic aesthetic. Instead, the company continued in a single chosen path, believing that it was the constant use of celebrities and the way they were shown in the advertisements, which was the key to success. Consequently, Pepsi employed celebrities that did not at all fit the company, being bigger or stronger than the brand itself, which lead to disastrous evaluation.

Pepsi itself seems to have noticed that their current strategies did not work out. So the company has recently changed their marketing agency and started the whole new campaign "Pepsi Refresh Project" which focuses on viral marketing and community development (Pepsi, 2015). It is still too early to say whether this campaign will work out or not, whether it even might transform Pepsi into an iconic brand once again. Following Holt (2004), who sees viral branding as clearly different from cultural branding and rather unable to build iconic brands, this is though highly unlikely. Believing that Pepsi still holds certain iconic properties, which could be helpful in building it into an iconic brand again, the author of this paper do however set aside these speculations and focus instead on the development of a new strategy for Pepsi by using the knowledge and strategies developed by Holt (2004), a task which will be undertaken in the next part.

\section{PART II - THE FUTURE}

To reach and build itself as an iconic brand, Pepsi should focus on its US market by following the ideas and the course of action outlined in the next sections:

\section{Current National Ideologies and Contradictions in the U.S. society}

First of all, Pepsi has to define an important contradiction in the US-American society to address. One can realize that in the recent post-crisis year, after a period of economic decline of 2007-2009, there is a swelled demand for a new national myth. Many Americans are still having a hard time, slowly accepting the fact that the lifestyle of buying on credit, which was common for last three generations, is vulnerable as a result of the financial crisis. The national ideology of a good life that is attainable for everyone who works hard is thus seriously threatened. As many Americans, especially young ones who only just started living independently, cannot afford to buy houses, cars or to pay autonomously for their education which otherwise could have been easily acquired using services of financial institutions (Rose and Hudgins, 2008). The ideals of both Hollywood and Pop stars do not seem up to date anymore since the lifestyles proceed. It provides a fruitful field for PepsiCo to bring in a new inspiring and helpful myth for the nation. As explained earlier, the author of this paper doubt whether the recent refreshment campaign is enough to turn Pepsi into an iconic brand. Instead, we suggest the company should focus on this current contradiction in the US society and, in broad terms, communicate the 'affordable lifestyle' rather than the 'popular lifestyle'.

As it is discussed in the first part of this paper, Pepsi's management uses extremely popular celebrities in their advertising campaigns, which does not seem to hit the spot anymore. As one possible alternative, the author suggest that less famous celebrities or maybe even "outdated" should be used, for example the actors from the Friends TVseries in an ironic, humorous way to advance a lifestyle centred on friendship. The aim of such an application would be: Firstly, the company would be more likely to be perceived as more close to the customers. Secondly, a new, more appropriate myth might be built, valuing friendship and living with friends higher than material goods (Holt, 2004). Consequently, the modification of Pepsi identity from being stuck with the celebrity endorsement to promote friendship ideology, becoming a 'friend' to the customer is being offered (Schroeder, 2006).

Developing this further, another suggestion for Pepsi is that the company can start focusing on the human factor. If a company is focusing on the formula of truly human behaviours and concepts such as 'friendship', the brand could communicate that like success, failure is normal in our daily life. As a strong company equipped with the necessary cultural authority (see below), Pepsi is confident enough to 
send those messages in its advertising campaigns. The brand's proposed role in the society is communicating that being not on top is normal and human (Holt, 2004).

\section{Possible Populist world and Identity Myths}

Populist worlds are established in the margins of the society. People in the populist worlds are neither seeking status nor being paid, but what unites them is the way they act according to their will. Populist worlds are found far away from the main brand customers. Holt argues that the iconic brands are partly built by people deeply immersed in populist worlds (Holt, 2004: 58).

Populist worlds are a source of material for the iconic brand, and these worlds can rise and fall over time (Holt, 2004: 199). One of the tasks of this paper was to find a new populist world for Pepsi to embody a new brand myth. This myth should encourage consumers to think differently about themselves and their lives. With the new populist world chosen for Pepsi, the author of this paper want to communicate that people should feel good about themselves though they are neither perfect nor successful. Therefore, the author chose to present known but not overly famous people who are successful in a variety of ways. These people should not be shown as they normally presented in the light of stable and confirmed success. Rather, a new angle should be used, showing the failures and problems of these people who made it, but who are struggling nevertheless. Thus, celebrities should be viewed from a "new" angle. It can demonstrate that celebrities are nothing but normal people who can fail and are likely to make mistakes and that this is nothing to be ashamed of. Everybody is somehow struggling with their lives, but it is crucial to keep on fighting and feel good about oneself. Therefore the new slogan should be "be human, stay cool".

\section{The "New" Cultural Brief for Pepsi - Campaigns and Advertisement}

Based on this, a new cultural brief (myth treatment, populist authenticity, charismatic aesthetic) can be outlined.

As for the myth treatment, Pepsi should employ aspiring individuals in its upcoming campaigns, people who struggled over the years before they made it and who could thus give inspiration to others. The underlying message should be that "you do not need a perfect home, family and appearance to become successful in your life, just be yourself and everything will be fine". Like Holt (2004) argues, the advertisements are not supposed to highlight unique benefits and features when communicating Pepsi to customers. Pepsi should find a valuable position in the national culture of the US. Still, some powerful advertising is needed.

Pepsi should also stop outsourcing their most critical strategic decisions from external agencies; they should take a step away from the mind-share model where the brand is agreed as a set of timeless concepts. The brand must be treated as a medium, like novels or films to deliver new materials that respond to the cultural needs of the society (Holt, 2004: 219). The Pepsi brand managers must also understand that consumers have become very cynical about their advertisements and and so be extra careful with about being authentic (Holt, 2004: 226).
Since advertising has become an endless parade of images, people are less and less attracted by these (Goldman and Papson, 1996). New sources must be found by brand managers to attract customers. According to Holt (2004) people forget the majority of the ads within weeks. So Pepsi should focus on some great performances that get the myth just right. If this is done successfully, other positive components will come automatically (Holt, 2004: 10). It is crucial that for iconic brands to perform ads that people love to watch because then people will share them, watch them again and tells stories about them (Holt, 2004: 225).

The author would like to see the advertisements of Pepsi take the form of a serial like a television program, though displayed not only on TV but also via other channels. While the media used should shift, the principles should remain the same. Examples of the content of these commercials could be the small and big mistakes and failures made by celebrities in their everyday lives - such as spilling red wine on the new white shirt one minute before a performance, having a hole in one sock when taking off their shoes, struggling with their kids in the supermarket, a famous song writer spilling coffee on his or her notes or struggling just to write a song, a successful entrepreneur like the founders of facebook, Google or other young yet successful companies sitting at home in front of the computer struggling with his work. In their crisis moment Pepsi is there to help. Be human, stay cool.

For all these ads, one style should be kept to form a charismatic aesthetic of the campaign. Fitting the content, the author recommends a documentary-style of work as opposite to the overly glamorous style of the last big commercials, all the while keeping the distinct red-white-blue colours of Pepsi. Gaining Populist authenticity would for Pepsi maybe be the hardest part of the exercise. If the company is to address the contradiction in society in the way proposed by the author, it has to deliver both literacy (through performances that helps to understand codes and idioms) and fidelity (by sacrificing broad-based popularity to stand up for ethos) of the populist world used (Holt, 2004: 65). This might prove difficult, since Pepsi cannot afford to sacrifice broad-based popularity. However, it might well worth the risk and in the end, to become more successful.

\section{Political and Cultural Authority}

The author is of the opinion that Pepsi can successfully promote a different lifestyle because it gained the authenticity to do so through its history. However, its authenticity and respectively customers' trust in brand have declined in the last years due to the mismatch in the advertising strategy undertaken earlier. The future task for company management is to regain authenticity by using techniques similar to the ones applied by Budweiser to re-establish its myth (Holt, 2004: 100). Following this example, Pepsi should redefine the concepts of a successful life, showing an alternative way of life in their advertisements, referring to the casual situations of both known and ordinary people. As for the image of Pepsi, consequently, the author would like to establish the myth that Pepsi understands and respects the problems of the nation. This is expressed in the suggested above motivating slogan: 'be human, stay cool'. In such a case, the Pepsi company can be rewarded as being called an iconic brand and, possibly, be "one 
of the most persuasive and cherished cultural leaders"of tomorrows American society (Holt, 2004:102).

\section{Building Trust}

When modifying its identity so that the main focus is on the attitude that being imperfect is good, Pepsi should at the same time try to increase the trust levels customers have in the company. Building trust is a tough but rewarding exercise. In this high opinion the communicated message should represent a stable meaning entailing moral aspects. They have to be openly communicated, so that the trust a brand acquired is 'confident' rather than 'ill-considered' (Gustafsson, 2005: 146). One idea would be to build trust via visibility of the upper management of the Pepsi Company. Trust might also be multiplied through consistent and credible statements about how the company works through all possible media channels, with the intention to tell the customers directly which values the company stands for. Besides, using managers of different levels in Pepsi's commercials might make the brand more credible and be more relevant than using only celebrities.

\section{Conclusion}

Having analyzed Pepsi's past and present branding efforts, achievements and failures, it could be clearly established that the brand that once held an iconic status is struggling now. Due to the over-use of celebrities instead of addressing relevant contradictions in society and helping citizens to build their identities, Pepsi has lost its status and is working hard yet unsuccessful on regaining it. As it is unclear whether the current "Refresh" campaign will be successful, the author outlined an alternative course of action for Pepsi which it should follow to regain its iconic status. First, the relevant contradiction in society was identified as being the gap between the ideal of leading an utterly successful and stable life in both the private (family, friends, house) and public (profession, outer appearance) spheres of life and the reality of being unable to do so due to external circumstances (i.e. financial and political crises leading to unemployment, debt, loosing houses). In order to resolve these contradictions, it was suggested that Pepsi, drawing on its once established political and cultural authority, should redefine the concept of a successful life by focusing on the human factor. The populist world that has been chosen for this are the private, less-successful moments of people otherwise portrayed as successful - actors, musicians, businessmen, entrepreneurs, with the resulting myth treatment - "be human, stay cool". Pepsi should gain populist authenticity by communicating its attitude through all possible channels and staying true to them, using a charismatic aesthetic of documentary style while keeping its blue, red and white colours. By following this course of action based on the principles of cultural branding, i.e. addressing a relevant contradiction in society in the right way, Pepsi might be able to become an iconic brand and continue to be one even in the future.

\section{REFERENCES}

Books

Bachmeier, Kristina (2008), Analysis of marketing strategies used by PepsiCo based on Ansoff's theory, Edition 2008.

Franzen, Giep and Moriarty, Sanda (2009), "The Science \& Art of Branding" M.E.Sharpe

Holt, Douglas B. (2004), "How Brands Become Icons: The Principles of Cultural Branding", Boston, MA: Harvard Business School.

Rose, P.S. \& Hudgins S.C. (2008), "Bank Management \& Financial Services", eighth ed., McGrawhill Irwin

Schroeder, Jonathan E. and Salzer-Mörling, Miriam (ed.) (2006), Brand Culture, London \& New York: Routledge.

\section{Articles and Book Chapters}

Bengtsson, Anders \& Jacob Ostberg (2007), "Researching the cultures of brands," in Handbook of qualitative research methods in marketing, Russell W. Belk (ed.): Edward Elgar Publishing, pp. 158-181.

Borgerson, Janet and Clara Gustafsson (2008), "Philosophy and Consumption: Discussions on trust and brands," peer-reviewed proceedings of Advances in Consumer Research, pp. 35, pp. 885-886.

Brown, Stephen (2001) "Torment Your Customers (They'll Love IT)," Harvard Business Review, vol. 79, no. 9, pp. 82-89.

Brown, Stephen, Robert V. Kozinets \& John F. Sherry Jr. (2003), "Teaching Old Brands New Tricks: Retro Branding and the Revival of Brand Meaning," Journal of Marketing, vol. 67, no. 3, pp. 19-33.

Csaba, F. F., \& Bengtsson, A. (2006). Rethinking identity in brand management. In J. E. Schroeder, \& M. Salzer-Mörling (Eds.), Brand Culture. (pp. 118-135). London: Routledge.

Fournier, Susan (1998), "Consumers and their Brands: Developing Relationship Theory in Consumer Research," Journal of Consumer Research, 24 (March), pp. 343-373.

Goldman, Robert \& Stephen Papson (1996), Sign Wars: The Cluttered Landscape of Advertising, New York, NY: The Guilford Press, pp. 20-35.

Gustafsson, Clara (2005) "Trust as an instance of asymmetrical reciprocity: An ethics perspective on corporate brand management," Business Ethics: A European Review, vol. 14, no. 2, pp. 142-150.

Gustafsson, Clara (2006), “Brand Trust and Authenticity: The Link between Trust in Brands and the Consumer's Role on the Market," peer-reviewed proceedings of European Advances in Consumer Research, 7, pp. 522-527.

Moraru, Madalina (2010) "The "positioning" concept and the fight between two well known brands Coca-Cola and Pepsi" Journal of Media Research, 7/2010, pp. 47-62

\section{Internet Sources}

Elliot, Stuart (2008), "Pepsi Shifts to a New Ad Agency", published: November 17, 2008, The New York Times, retrieved 04.02.2015 from <http:/ / www.nytimes.com/2008/11/18/business/media/18 adco.html?_r=1>

Kilmer \& Kilmer (2001),"Speak Brand", Kilmer \& Kilmer, Inc., retrieved 04.02.2015 from <http://www.kilmer2.com/knowledge/article_02.aspx>

Pepsi (2015), <www.pepsi.com>, last accessed 08.02.2015

Wikipedia (2015), "American Dream", Wikipedia, the free encyclopaedia. $\quad$ Retrieved 16.02.2015 from $<$ http://en.wikipedia.org/wiki/American_Dream>

Wikipedia (2015), "PepsiCo", Wikipedia, The Free encyclopedia. Retrieved 06.02.2015 $<$ http://en.wikipedia.org/wiki/PepsiCo>

$--0--$ 